\title{
The impact of sociodemographic factors on academic achievements among high school students in Indonesia
}

\author{
Deri Indrahadi, Amika Wardana \\ Faculty of Social Science, Universitas Negeri Yogyakarta, Indonesia
}

\begin{tabular}{l} 
Article Info \\
\hline Article history: \\
Received Mar 9, 2020 \\
Revised Sep 30, 2020 \\
Accepted Oct 13, 2020 \\
\hline
\end{tabular}

\section{Keywords:}

Academic achievement

High school

Sociodemographic

Student

\begin{abstract}
This study aimed to examine the effect of sociodemographic, student and school factors on the academic achievement of high school students in Indonesia. Using the cross-sectional survey data from the 2015 Indonesian Family Life Survey (IFLS) particularly involving 1,421 respondents (of the academic performances during their school years), the study run multiple regression analysis to examine the influences of their parents' sociodemographic, students and other school-related factors on their academic achievements during their school years. As the results, it was revealed that the sociodemographic factors, students and schools predict significantly academic achievement of students in Indonesia. The results provided feedback to students and parents, schools and education policymakers in improving student academic achievement.
\end{abstract}

This is an open access article under the CC BY-SA license.

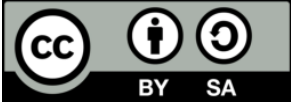

\section{Corresponding Author:}

Amika Wardana,

Department of Sociology Education,

Faculty of Social Science,

Universitas Negeri Yogyakarta,

1st Colombo Street, Karangmalang, Yogyakarta, Indonesia.

email: a.wardana@uny.ac.id

\section{INTRODUCTION}

Academic achievement is the focus of an important study which is a measure of the quality of education in all countries. Academic achievement of students in secondary schools in Indonesia has been highlighted quite sharply in recent years. Education in Indonesia shows that quality is not guaranteed and equity is not maximized for all high schools in Indonesia [1]. A report from the World Bank reveals that the overall quality of secondary schools in Indonesia is quite low [2]. his is supported by the Program for International Student Assessment (PISA) report in 2012 revealing that the academic achievement of students in Indonesia is still very low in mathematics, language and science. Indonesia is ranked 64th out of 65 countries that are members of the OECD [3].

However, a major problem is research that seeks to investigate various factors that cause student achievement in Indonesia that has not been encouraging is still very minimal. Several studies examining student achievement in Indonesia were carried out in the context of the general education system [4]. One study tried to investigate the non-academic factors that affect the performance of high school $9^{\text {th }}$-grade students. The findings of the study indicate that family capital, parental education, and parental expectations, number of school teachers, condition of school facilities, number of lessons per week for a subject, teacher qualifications, teacher lesson plans and assessment plans, and teacher and head feedback school about instruction [5]. Other studies have sought to examine the choice of school types for high school students affecting student achievement. In addition, these findings state that students who attend public high school get better test scores than those who attend private schools [6]. 
Other studies examining the relationship between teacher quality in relation to student achievement in Indonesia revealed that teacher quality, in terms of teacher evaluation scores, was a problem and was tested statistically significant to students' academic achievement at the high school level [7]. Some of these studies have provided an overview of the factors that affect student academic achievements. Yet, those studies had not examined the effect of factors outside the school, tachers, curriculum, and learning on the academic achievement. Bsed on that, this study aimed to examine factors outside the school, teacher, curriculum and learning that affect student academic achievement in Indonesia. The academic achievement refer the efforts to measure of the extent to which students, teachers, or institutions have achieved educational goals. Although there is no general agreement in measuring academic achievement, this has done measured through test scores, final exams, or national exams. In this study, we define academic achievement broadly, including achievement (measured by progress in school, graduation, and subsequent participation in higher education) as well as academic skills and knowledge [8]. The academic achievement is an important study topic in several countries in the world, both developed and developing countries and underdeveloped countries. All this is related to the fact that academic achievement is an important tool that can be used to evaluate the quality of education and how the quality of education is guaranteed [9]. Research in the last few decades shows that academic achievement is one of the most widely studied aspects in the field of education. The study focused on the causal relationships of several indicators on academic achievement [10].

Moreover, academic achievement plays an important role in producing high-quality, best graduates who will become leaders and great human resources for the country so that they are responsible for the economic and social development of the country [5]. High academic achievement indicates different abilities between students [11]. Academic achievement is an indicator of a student's academic success and a part of determining student graduation at school [12]. It could be said that the study on students' academic achievement has become an aspect of improving student academic qualities in general senses.

Currently, a number of internatioally recognised institutions have measured yearly students' academic achievement in various countries. For example, the PISA which is managed by the Organization for Economic Cooperation and Development (OECD) has examined and provided information about a country's academic achievement [13]. In addition to measuring student academic restoration, PISA also examines the factors that influence it. Learning, curriculum, school, and education system are considered four factors that influence student academic achievement. Learner factors include the gender of students, the socioeconomic status of their family, motivation (interest in learning, level of participation, and selfconfidence), expectations for education. Curriculum factors include teaching strategies, the class atmosphere felt by students, class size, teacher support for student learning and life, use of textbooks, and so on. Factors at the school level include the type of school management (public or private), structure, quality of teaching staff, number of computers, culture (behavior and ethics of students and teaching staff), and school management, class practices (classroom teaching activities, student evaluations, hours of study, classroom monitoring by the teacher) and so on [14].

Nevertheless, other studies had also measured the factors that affect academic achievement such as student factors including demographic information such as gender and age of race, ethnicity, socioeconomic status [15]. Factors related to learning, teacher factors including demographic information, teacher experience, student academic expectations, teacher support [16]. School factors which include demographic information such as school type, location, and school facilities. Then the last factor outside the school, including the educational environment at home, the use of time off. Most recent empirical studies use indicators commonly used in previous studies. Student academic achievement is measured by several indicators such as sociodemographic factors, student factors, teacher factors, and school factors. While other studies grouped into personal variables, related to family, related to school, and social [17].

\section{RESEARCH METHOD}

\subsection{Data set}

The data were taken from the Indonesian Family Lifehood Survey (IFLS) 5 released 2015 in late 2014 and early 2015 by Rand and Survey Meters. the IFLS is a longitudinal data based on surveys involving respondents representing $80 \%$ regions of the entire Indonesian population who lived in 13 of the 26 provinces started in 1993 based on a household sample. The IFLS 4 had surveyed about 30.000 respondents on various socio-economic and sociodemographic variables at the individual, family, household and community level in which they live, and includes education and employment $[18,19]$. The IFLS data is considered still relevan to date and there have been many studies conducted using IFLS data [20-23]. Student academic achievement data obtained from the IFLS is still relevant compared to student academic achievement data from The Ministry of Education and Culture [24]. 


\subsection{Measurement}

The primary data on measuring the academic achievement taken from the result of Grade 12 national exam scores as provided in the IFLS data. In this study, it took scores from reading and mathematics subjects. The average reading scores is 6.99 and the average math scores is 6.92 . We use dummy variables to measure overall sociodemographic variables. For gender, male are coded $=1$ and female are coded $=0$. Ethnic Javanese are coded $=1$ and non Javanese is coded $=0$. Housing in the city is coded $=1$ and village is coded $=0$. We also use dummy variables to measure student factor variables. For the experience of attendance at children's parks are coded $=1$ and those who do not attend children's parks are coded $=0$. Internet use is coded $=1$ and not using the internet is coded $=0$. Extracurricular activities are coded with $=1$ and not following extracurricular activities are coded with $=0$. The three school factor variables including type of school and the use of textbooks were measured using dummy variables. Public schools are coded with $=1$ and private schools are coded with $=0$. Religious affiliation schools are coded with $=1$ and nonreligious affiliation schools are coded with $=0$. In addition, some school variables including class size, school distance, and hours of study per day are measured on a ratio scale. Class size is measured by how many students there are in the class. School distance is measured by the time taken (minutes) from home to school. Hours of study per day are measured by the length of study in class in a day.

\subsection{Statistical analysis}

The use of quantative studies is a well-established approach in this to examined the effect of related variables on academic achievement. The collected data were analyzed by conducting statistical analysis in two steps, 1) descriptive and correlation; 2) and regression analysis. Descriptive statistics are used to see the distribution of data while correlation analysis is intended to examine the relationship between variables, the significant effects of various factors including sociodemographic, student, and school on academic achievement are explored by multiple linear regression using R statistical Software [25]. Correlation analysis to determine the relationship between two variables. The strength of the relationship between two two variables is seen from the correlation coefficient. We perform multiple regression with two or more independent variables. Multiple regression is carried out with the aim to measure the factors that contribute to student academic achievement. Multiple linear regression is carried out in four steps to show the relative effect of each variable on school achievement [4].

\section{RESULTS AND DISCUSSION}

Based on the result on the Table 1, the descriptive statistical including the mean and standard deviation of all variables measured in this study. The total sample of 1,421 students including male and female representing all schools in Indonesia. The table also shows the results of statistical correlations between sociodemographic variables, student, and school with reading and mathematics scores. All variables correlate significantly with academic achievement so that they meet the conditions for the regression test. There is a negative correlation observed in students' reading and metematics scores, religious affiliation schools, class size, and school distance (minutes), while other variables are positively correlated. Urban status is the sociodemographic variable that is most strongly correlated to student academic achievement, while experience attending children's parks is most strongly correlated to student academic achievement from student variables. Then, class size also shows a strong correlation of school variables predicting student academic achievement in both reading and mathematics score. The results of the regression analysis of the factors that contributed to reading and mathematics scores are presented on the Table 2. There are several possible explanations for this result. The results showed that the greatest positive and significant influence on reading and mathematics scores at the sociodemographic level were Javanese $(\beta=0.24, p<0.001)$ and $(\beta=$ $0.24, \mathrm{p}<0.001)$. Another significant effect on the sociodemographic level was gender, female students were more likely than male students to achieve academic achievement $(\beta=0.20, p<0.001)$ for reading scores and $(\beta=0.21, \mathrm{p}<0.001)$ for mathematics scores. Urban status has little effect on academic achievement also evident in the model. 
Table 1. Decriptive statistic and summary of correlation analysis

\begin{tabular}{|c|c|c|c|c|c|}
\hline & \multirow{2}{*}{ Variables } & \multirow{2}{*}{ Mean } & \multirow{2}{*}{$\begin{array}{c}\text { Standart } \\
\text { Deviation }\end{array}$} & \multicolumn{2}{|c|}{ Correlation Analysis } \\
\hline & & & & Reading & Math \\
\hline \multirow{3}{*}{$\begin{array}{c}\text { Sociodemographics } \\
\text { Factors }\end{array}$} & Female & 0.51 & .49 & $0.09 *$ & $0.09^{*}$ \\
\hline & Javanese & 0.56 & .49 & $0.13 *$ & $0.12 *$ \\
\hline & Urban & 0.43 & .50 & $0.17 *$ & $0.19 *$ \\
\hline \multirow{3}{*}{ Students Factors } & Kindergarten Attendance & 0.49 & .50 & $0.13^{*}$ & $0.12 *$ \\
\hline & Internet Use & 0.82 & .38 & $0.11 *$ & $0.9 *$ \\
\hline & Extracurricular Activities & 0.55 & 7.3 & $0.08 *$ & $0.08^{*}$ \\
\hline \multirow{6}{*}{ School Factors } & Public School & 0.53 & .49 & $0.09^{*}$ & $0.13^{*}$ \\
\hline & Religious Affiliation School & 0.28 & .45 & $-0.14 *$ & $-0.17 *$ \\
\hline & Class Size & 32.4 & 7.9 & $-0.26 *$ & $-0.21 *$ \\
\hline & School Distance (Minutes) & 22.2 & 18.5 & $-0.18 *$ & $-0.13^{*}$ \\
\hline & Average Hours/Week in School & 32.3 & 12.1 & $0.06^{*}$ & $0.09 *$ \\
\hline & Textbook Use & 0.82 & .26 & $0.12 *$ & $0.12 *$ \\
\hline
\end{tabular}

$\mathrm{n}=1.421$ IFLS Samples. Reported associations are the coefficients of Spearman correlation, $* p<.05$

At the student factor, the largest and significant effect on reading and math scores were kindergarten attendance experience $(\beta=0.21, \mathrm{p}<0.001)$ and $(\beta=0.22, \mathrm{p}<0.001)$. Internet use also showed a significant effect on reading and mathematics scores with $(\beta=0.19, \mathrm{p}<0.001)$. Extracurricular activities in the below results table show a weak and insignificant influence.

At the school factors, the largest and significant effect on reading and math scores were public schools $(\beta=0.27, \mathrm{p}<0.001)$ and $(\beta=0.28, \mathrm{p}<0.001)$, class size $(\beta=-0.24, \mathrm{p}<0.001)$ and $(\beta=-0.23, \mathrm{p}$ $<0.001)$, use of textbook $(\beta=0.12, \mathrm{p}<0.001)$ and $(\beta=0.11, \mathrm{p}<0.001)$, religious affiliation school $(\beta=-0.12$, $p<0.001)$ and $(\beta=-0.12, p<0.001)$, and Average Hours/week in School $(\beta=-0.11, p<0.001)$ and $(\beta=-0.13$, $\mathrm{p}<0.001)$. The school distance has little and less significant effects also reported on the Table 2.

Table 2. Multiple linier regression analysis

\begin{tabular}{|c|c|c|}
\hline \multirow{2}{*}{ Variables } & \multicolumn{2}{|c|}{ Estimate $(\mathrm{t})$} \\
\hline & Reading & Math \\
\hline Female & $0.20 * * *$ & $0.21 * * *$ \\
\hline Javanese & $0.24 * * *$ & $0.24 * * *$ \\
\hline Urban & $0.7 * *$ & $0.7 * *$ \\
\hline Kindergarten Attendance & $0.21 * *$ & $0.22 * *$ \\
\hline Internet Use & $0.19 * * *$ & $0.19 * * *$ \\
\hline Extracurricular Activities & 0.07 & 0.07 \\
\hline Public School & $0.27 * * *$ & $0.28 * * *$ \\
\hline Religious Affiliation School & $-0.12 * *$ & $-0.12 * *$ \\
\hline Class Size & $-0.24 * * *$ & $-0.23 * * *$ \\
\hline School Distance (Minute) & $-0.05^{*}$ & $-0.05^{*}$ \\
\hline Average Hours/week in School & $-0.11 * *$ & $-0.13 * *$ \\
\hline Textbook Use & $0.12 *$ & $0.11 *$ \\
\hline $\mathrm{R}^{2}$ & $0.32 * * *$ & $0.33 * * *$ \\
\hline
\end{tabular}

Based on the result of regression analysis, there are various factors that affect student academic achievement, both school factors and factors outside the school. In this case, using nationally representative data, this study focuses on exploring the influence of various factors including sociodemographic, student, and school factors directly on the academic achievement of high school students from reading and mathematics grades. To achieve good academic quality it is necessary for all parties involved to understand the factors that contribute to improving student academic achievement. Overall, the results of this study indicate that sociodemographic factors, students, and schools can predict student academic achievement.

Based on statistical results, this study shows that factors outside school, teacher, curriculum, and learning have a significant effect on student academic achievement. The finding of the current study consists of prior studies that have documented a positive effect of sociodemographic, student, and school factors on students academic achievement $[6,25,26]$. However, the finding of current studies does not support the previous research [27, 28]. Study on sociodemographic indicators to find factors that influence student academic performance. These factors include parental education, parental occupation, parental income, gender, type of school and including school location [29]. Gender has become one of the factors studied in research related to student academic achievement. Female students scored significantly better than male students in mathematics and reading. In addition, that result also indicated that student in urban better than a student in rural on academic achievement. 
Sociodemographics are the strongest factors influencing students' academic achievement [1, 30-33]. Analysis of the relationship between academic achievement and factors relating to students, teachers, schools, learning, and other factors can provide important morning information on education policy makers and make certain interventions in an effort to improve the quality of education.

Based on statistical results, several important findings are described in this section. First, our hypothesis about the relationship and prediction of each factor on student achievement in the regression model as a whole supports the initial hypothesis. However, several factors were found to have weak relationships and influences and contrasted with previous theories and findings. The surprising finding is that students from Javanese ethnic group get better grades than students from outside Javanese, studies related to ethnicity and academic achievement of students in Indonesia have never been tested before. This study is the first finding related to differences in student achievement in Indonesia based on ethnic background. In addition, female students received higher reading and math scores than male students. However, researcher note that gender or sex differences in academic achievement have not shown consistent results. Then, students from urban areas get better reading and mathematical results compared to students from rural. Students in rural areas are disadvantaged by this condition, this is because students from rural experience various obstacles including financial problems [34].

Other main finding shows student factors affecting student academic achievement. Confirming prior studies, our findings prove the effect of kindergarten attendance has a positive influence on student academic achievement $[35,36]$. Based on the findings of [35] revealed that attendance in children's parks has a longterm effect on student development. Students who attend kindergarten get a learning experience and are better prepared to study in the next class, and ultimately have a good impact on students' academic achievement at school. Our findings also indicate that internet use increase student academic achievement. The use of the internet has a positive effect on student academic achievement, this study illustrates significant results $[37,38]$.

Several other findings show the negative effect of the use of the internet on student academic achievement $[39,40]$. Furthermore, this study explains the impact of using the internet as a medium to help student learning. Students who use the internet can help their learning process and ultimately can improve academic achievement [38]. Surprisingly, we also find the weak influence of extracurricular activities on reading and mathematics achievement. The traditional finding indicated that the strength effect of extracurricular activities on student reading and math scores [27]. This result has not previously been described. This illustrates finding contradicts previous studies [28, 41]. Previous study have documented that extracurricular activities are important component and cannot be separated from school life [42]. Student participation in extracurricular activities such as sport, arts, academics club, and school organizations provides experiences for student and plays a role in improving academic achievement [28].

Our findings also reveal some factors that contribute to academic achievement among Indonesian senior high school students. School choice can affect student academic achievement. Recent study shows that students who attend public schools get better scores than students who attend private schools. Meanwhile, students who attend schools affiliated with religious institutions get lower reading and math scores than students who attend schools that are not affiliated with religious institutions (general). This supports the findings of previous studies [6]. In addition, we found a significant effect on class size on students' academic achievement. Students who are in large classes or with large numbers of students have a negative impact on reading and mathematics scores. Our finding show that the effect of this class size on student academic achievement. Our finding indicate that small class increases in student acadedmic achievement. Previous research revealed that reducing class size can increase student academic achievement [42-45].

Our findings also show negative effect of school distance on student academic achievement. Student's who spend more than thirty minutes from home to school adersely affect academic achievement. Prior studies have documented that the greater distance traveled and time spent going to school can have a negative impact on student academic performance [46]. In addition, other studies have found that the effects of longer school days or study time can affect students' reading and math scores, but this effect has not been consistent [47, 48]. Our last finding show positive effect of using textbook on academic achievement. Textbook as a learning media has a strong effect on students' achievement. The use of student textbooks is considered to have a positive impact on student academic achievement especially on mathematics scores, it's confirm prior study (school facilities). The use of textbooks can help students in learning and have impact on achievement. These results provides intervention and suggest the provision of textbook by schools and their used by theachers and students. 


\section{CONCLUSION}

This study was to investigate sociodemographic, student, and school factor on student academic achievement. The study found that students' academic achievement was influenced by factors including sociodemographics, students, and schools. The findings of this study are complex, this requires careful interpretation of this because there are variables that have strong and weak influence. Based on information obtained from the results of this study, it is expected to become a consideration for policy making in the field of education in Indonesia to improve student academic achievement.

Finally, some limitations in this study must be followed up for future research. The first limitation is that not all the findings of this study can prove the previous findings, this illustrates the complexity in the relationship between the factors that affect student academic achievement in Indonesia. But far more meaningful this research can be a reference for educational policy making and for future studies. Second, future research is expected to examine other factors that can affect reading and mathematics achievement. As explained above, the teacher and learning factors have been widely studied in their effects on academic achievement. Third, this study collected cross-section data from the IFLS in 2014, it is far better for future research to collect panel data to study academic achievement of students in Indonesia.

\section{REFERENCES}

[1] R. Ohno, "Study on Regional Disparity of Academic Achievement in Indonesia," ASSEHR 2nd International Conference on Research of Educational Administration and Management (ICREAM, 2018), Atlantis Press, pp. 212-215, 2019.

[2] World Bank, "Indonesia : Achievements in Education Over the Last 10 Years Indonesia : Size and role of Private Sector," 2012.

[3] Pisa, "PISA 2012 Results in Focus," 2012.

[4] S. J. Caldas and C. Bankston, "Effect of School Population Socioeconomic Status on Individual Academic Achievement," The J. of Educ. Res, vol. 90, no. 5, pp. 37-41, 1997.

[5] M. Ali and B. Hayat, "Non-academic factors influencing students' achievement: A study in the Indonesian madrasahs," Int. J. Learn. Intellect. Cap., vol. 16, no. 2, pp. 180-192, 2019.

[6] David and K. Beegle, "Board of Regents of the University of Wisconsin System The Effect of School Type on Academic Achievement : Evidence from Indonesia," Human, vol. 41, no. 3, pp. 529-557, 2006.

[7] S. Sirait, "Does Teacher Quality Affect Student Achievement? An Empirical Study in Indonesia.," J. Educ. Pract., vol. 7, no. 27, pp. 34-41, 2016.

[8] B. P. Gill, P. M. Timpane, K. E. Ross, and D. J. Brewer, "What We Know and What We Need To Know About Vouchers and Charter Schools," in Rhetoric vs. Reality, pp. 69-114, 2001.

[9] Z. Sun and H. Tian, "Academic Achievement Assessment - Principles and Methodology," 2018

[10] T. Guse and Y. Vermaak, "Hope, Psychosocial Well-Being and Socioeconomic Status Among a Group of South African Adolescents," J. Psychol. Africa, vol. 21, no. 4, pp. 527-533, 2014.

[11] U. Saprudin, Wahjoedi, Widiati, "Correlation analysis of parents' socioeconomic conditions and self-efficacy on learning achievement ips (in Bahasa),” J. Pendidik. Teor. Penelitian, dan Pengemb., vol. 2, no. 10, pp. 1388-1392, 2017.

[12] S. T. Kurniawati, D. M. Handarini, C. L. Radjah, "The influence of achievement motivation and academic selfconcept on academic achievement of public junior high school students in Malang," J. Pendidik. Teor. Penelitian, dan Pengemb., vol. 1, no. 12, pp. 2337-2344, 2016.

[13] J. Anders, "Oxford Review of Education The influence of socioeconomic status on changes in young people's expectations of applying to university," Oxford Rev. Educ., vol. 4985, no. June, pp. 1-21, 2017.

[14] S. G. Rivkin, E. A. Hanushek, J. F. Kain, B. Y. S. G. Rivkin, E. A. Hanushek, and J. E. Kain, "Teachers, Schools, and Academic Achievement," Econometrica, vol. 73, no. 2, pp. 417-458, 2005.

[15] S. Ranjan, N. Brac, and E. Division, "Factors influencing primary students' learning achievement in Bangladesh," Res. Educ., vol. 88, no. 1, pp. 50-63, 2012.

[16] A. T. Payandeh Najafabadi, M. O. Najafabadi, and M. R. Farid-Rohani, "Factors contributing to academic achievement: A Bayesian structure equation modelling study," Int. J. Math. Educ. Sci. Technol., vol. 44, no. 4, pp. 490-500, 2013

[17] C. G. Barbera, J. C. Niebla, K. D. López, and M. L. Ortega, "Rendimiento académico y factores asociados. Aportaciones de algunas evaluaciones a gran escala," Bordon, vol. 64, no. 2, pp. 51-68, 2012.

[18] D. Thomas, et al., "Cutting the costs of attrition: Results from the Indonesia Family Life Survey," Journal of Development Economics, vol. 98, no. 1, pp. 108-123, 2012.

[19] J. Strauss, F. Witoelar, and B. Sikoki, "User's Guide for the Indonesia Family Life Survey," Wave 5, 2016. [Online]. Available: www.rand.org

[20] D. Krisanti, N. Prihartono, "Obesity as a predictor of hypertension in adult population: A14-years retrospective cohort study," Indian Jour. Publ. Heal. Res. \& Dev., vol. 10, no. 6, pp. 491-497, 2019.

[21] I. Auwalin, "Ethnic identity and internal migration decision in Indonesia," Jour. of Ethn. and Migr. Stud, vol. 46, no. 23, pp. 2841-2861, 2020.

[22] D. Erlangga, S. Ali, and K. Bloor, "The impact of public health insurance on healthcare utilisation in Indonesia: evidence from panel data," Int. J. of Publ. Hea., vol. 64, no. 14, pp. 603-613, 2019. 
[23] S. Sujarwoto, G. Tampubolon, and A.C. Pierewan, "A tool to help or harm? online social media use and adult mental health in Indonesia," Int. J. of Mental Heal. and Addic., vol. 17, no. 4, pp. 1076-1093, 2019.

[24] Kementerian Pendidikan dan Kebudayaan, "Pusat Penilaian Pendidikan," 2020. [Online]. Available: pusendik.kemendikbud.go.id

[25] G. N. Kimani, A. M. Kara, and L. W. Njagi, "Teacher Factors Influencing Students' Academic Achievement in Secondary Schools in Nyandarua County, Kenya," Int. J. Educ. Res., vol. 1, no. 3, pp. 1-14, 2013.

[26] J. Liu, P. Peng, and L. Luo, "The Relation Between Family Socioeconomic Status and Academic Achievement in China: A Meta-analysis," Educ. Psychol. Rev., vol. 32, pp. 49-76, 2019. [Online]. Available: https://doi.org/10.1007/s10648-019-09494-0

[27] K. J. Abruzzo, C. Lenis, Y. V Romero, K. J. Maser, and E.-S. Morote, "Does Participation in Extracurricular Activities Impact Student Achievement?,” J. Leadersh. Instr., vol. 15, no. 1, pp. 21-26, 2016.

[28] J. A. Fredricks, "Extracurricular Participation and Academic Outcomes : Testing the Over-Scheduling Hypothesis," J Youth Adolesc., vol. 41, no. 3, pp. 295-306, 2012.

[29] S. Helal, J. Li, L. Liu, E. Ebrahimie, S. Dawson, and D. J. Murray, "Identifying key factors of student academic performance by subgroup discovery," Int. J. Data Sci. Anal., vol. 7, no. 3, pp. 227-245, 2019.

[30] I. Altschul, "Linking Socioeconomic Status to the Academic Achievement of Mexican American Youth Through Parent Involvement in Education," J. Soc. Social Work Res., vol. 3, no. 1, pp. 13-30, 2012.

[31] G. J. Duncan, P. A. Morris, and C. Rodrigues, "Does Money Really Matter? Estimating Impacts of Family Income on Young Children's Achievement With Data From Random-Assignment Experiments," Dev Psychol., vol. 47, no. 5, pp. 1263-1279, 2011.

[32] H. Long and W. Pang, "Family Socioeconomic Status, Parental Expectations, and Adolescents' Academic Achievements : A Case of China," Educ. Res. Eval., vol. 22, no. 5-6, pp. 283-304, 2016.

[33] A. Raychaudhuri and M. Debnath, "Factors Affecting Students' Academic Performance: A case study in Agartala Municipal Council Area.," E-Journal, vol. 7, no. July, pp. 34-41, 2010.

[34] C. a. Semke and S. M. Sheridan, "Family-school connections in rural educational settings : A systematic review of the empirical literature," Natl. Cent. Res. Rural Educ., vol. 22, no. 1, pp. 1-29, 2011.

[35] E. M. Joe, J. E. Davis, J. Earl, and D. Temple, "Parental Influence, School Readiness and Early Academic Achievement of African American Boys," The Journal of Negro Education, vol. 78, no. 3, pp. 102-113, 2016.

[36] V. Allhusen, et al., "Age of entry to kindergarten and children's academic achievement and socioemotional development," Early Educ. Dev, vol. 18, no. 2, pp. 337-368, 2007.

[37] S. Judge, "The impact of computer technology on academic achievement of young African American children," $J$. Res. Child. Educ., vol. 20, no. 2, pp. 91-101, 2005.

[38] L. A. Jackson, A. Von Eye, F. A. Biocca, G. Barbatsis, Y. Zhao, and H. E. Fitzgerald, "Does home Internet use influence the academic performance of low-income children?" Dev. Psychol., vol. 42, no. 3, pp. 429-435, 2006.

[39] V. Stavropoulos, K. Alexandraki, and F. Motti-Stefanidi, "Recognizing internet addiction: Prevalence and relationship to academic achievement in adolescents enrolled in urban and rural Greek high schools," J. Adolesc., vol. 36, no. 3, pp. 565-576, 2013.

[40] S. M. Lee, W. Brescia, and D. Kissinger, "Computer use and academic development in secondary schools," Comput. Sch., vol. 26, no. 3, pp. 224-235, 2009.

[41] R. Yeung, "Athletics, Athletic Leadership, and Academic Achievement," Educ. Urban Soc., vol. 47, no. 3, pp. 361-387, 2015.

[42] B. Nye, L. V. Hedges, and S. Konstantopoulos, "The effects of small classes on academic achievement: The results of the Tennessee class size experiment," Am. Educ. Res. J., vol. 37, no. 1, pp. 123-151, 2000.

[43] Y. Shin and S. W. Raudenbush, "The causal effect of class size on academic achievement: Multivariate instrumental variable estimators with data missing at random," J. Educ. Behav. Stat., vol. 36, no. 2, pp. 154-185, 2011.

[44] T. Shen and S. Konstantopoulos, "Class size effects on reading achievement in Europe: Evidence from PIRLS," Stud. Educ. Eval., vol. 53, no. November, pp. 98-114, 2017.

[45] J. D. Finn, "Academic and non-cognitive effects of small classes," Int. J. Educ. Res., vol. 96, no. May, pp. 125-135, 2019.

[46] C. Vieira, I. Vieira, and L. Raposo, "Distance and academic performance in higher education," Spat. Econ. Anal., vol. 13 , no. 1 , pp. $60-79,2018$.

[47] E. Meyer and C. Van Klaveren, "The effectiveness of extended day programs: Evidence from a randomized field experiment in the Netherlands," Econ. Educ. Rev., vol. 36, no. October, pp. 1-11, 2013.

[48] M. Huebener, S. Kuger, and J. Marcus, "Increased instruction hours and the widening gap in student performance," Labour Econ., vol. 47, no. November, pp. 15-34, 2017. 